\title{
ACCELERATOR COMPLEX FOR A RADIOACTIVE ION BEAM FACILITY AT ATLAS
}

\author{
J.A. Nolen, Physics Division, Argonne National Laboratory, Argonne, IL 60439
}

Since the superconducting heavy ion linac ATLAS is an ideal post-accelerator for radioactive beams, plans are being developed for expansion of the facility with the addition of a driver accelerator, a production target/ion source combination, and a low $\mathrm{q} / \mathrm{m}$ pre-accelerator for radioactive ions. A working group including staff from the ANL Physics Division and current ATLAS users are preparing a radioactive beam facility proposal. The present paper reviews the specifications of the accelerators required for the facility.

\section{INTRODUCTION}

There is much enthusiasm in the nuclear physics research community for the opportunities for studies which would be enabled by an advanced, high intensity accelerated radioactive beam facility based on the isotope-separator on- line (ISOL) method. There are recent reports from both North American and European study groups $[1,2]$. A group including many ANL Physics Division staff and ATLAS outside users has discussed the research possibilities and prepared a working paper entiled "Concept for an Advanced Exotic Beam Facilitty Based on ATLAS." This paper is available on the World Wide Web at the ANL Physics Division home page (http://www.phy.anl.gov). This paper summarizes the accelerator complex proposed in the working paper.

A schematic layout of the conceived facility is shown below in Fig. 1. The existing ATLAS accelerators and experimental facilities are in the lower part of the figure, and the proposed driver linac, production target area, mass separators, new low energy experimental areas, and post accelerator injector are in the upper part.

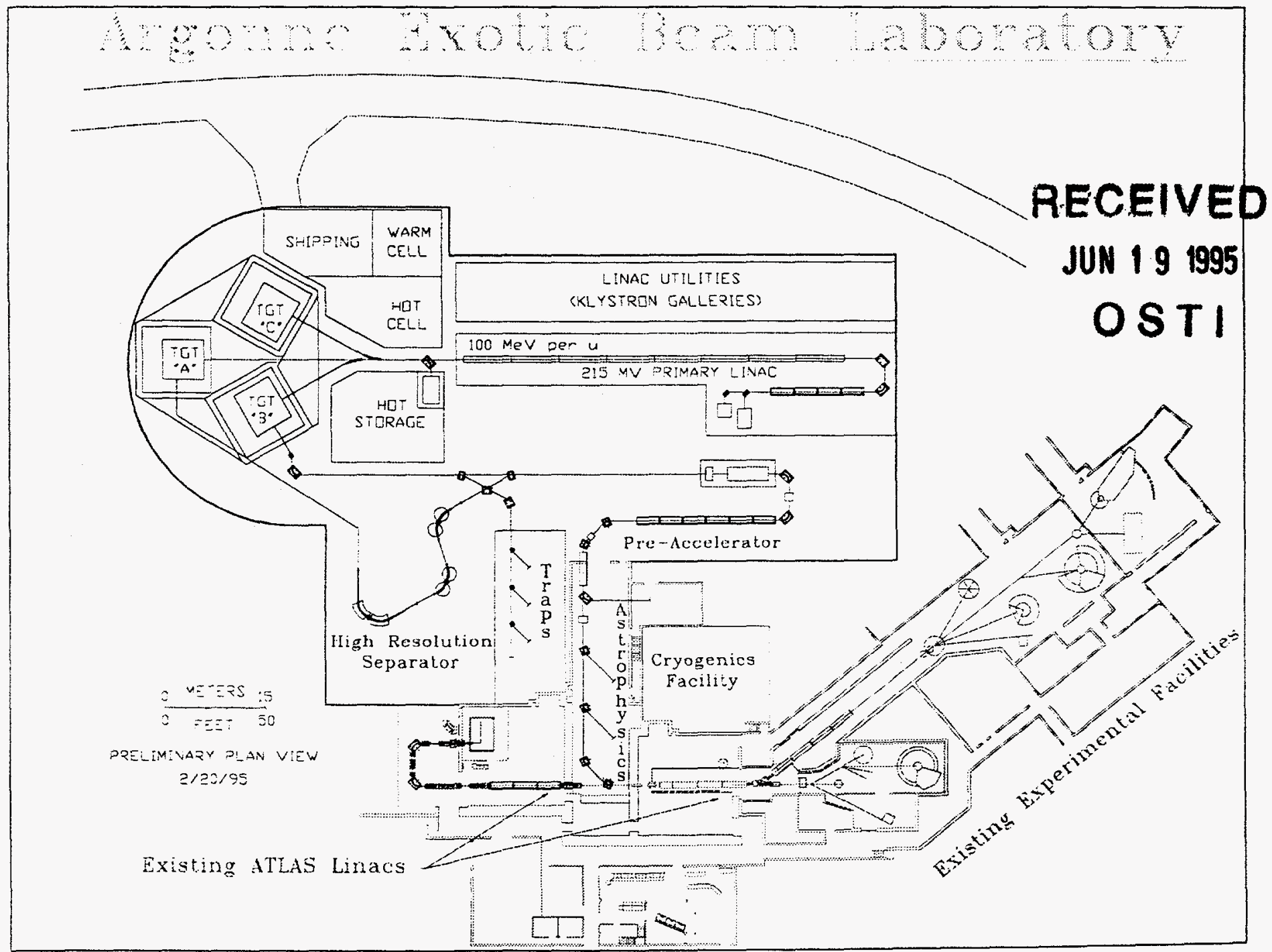

Figure 1. Schematic layout of the present ATLAS accelerators and experimental facilities (lower part of the figure) and the proposed additions to the facility (upper part). 


\section{DISCLAIMER}

Portions of this document may be illegible in electronic image products. Images are produced from the best available original document. 
Table I. Beam parameters of the Production Linac

Max Output Beam Energy:

Max Output Beam Power:

Typical Light Ions (multicusp ion source):

Typical Heavy Ions (pulsed ECR ion source):

Typical Max. Light Ion Currents @100 kW:

Typical Max. Heavy Ion Currents @ 100 kW:

Typical Heavy Ion Source/Stripping Limits:
$100 \mathrm{MeV}$ per nucleon ${ }^{\circ *}$

$100 \mathrm{~kW}$

$1_{\mathrm{H},}{ }^{2} \mathrm{H},{ }^{\mathrm{He}}$

$12 \mathrm{C}^{2+, 6+; 16,18} \mathrm{O}^{3+, 8+} ; 20,22 \mathrm{Ne}^{4+, 10+; 36} \mathrm{Ar}^{6+, 16+}$

${ }^{1} \mathrm{H}, 1000 \mathrm{p \mu A} ;{ }^{2} \mathrm{H}, 500 \mathrm{p \mu A} ;{ }^{4} \mathrm{He}, 250$ puA

${ }^{18} \mathrm{O}^{8+}, 55 \mathrm{p \mu A} ;{ }^{36} \mathrm{Ar}^{16+}, 28 \mathrm{p} \mu \mathrm{A}$

${ }^{18} \mathrm{O}^{8+}, 20 \mathrm{p} \mu \mathrm{A} ;{ }^{36} \mathrm{Ar}^{16+}, 3 \mathrm{p} \mu \mathrm{A}$
As indicated in Fig. 1 the new components for the radioactive beam laboratory will be constructed in a new building just north of the present ATLAS facility. Radionuclides are produced by irradiating targets in well-shielded areas with light ion beams from a modern drift tube linac. The present plan is for the primary linac and production targets to be located below grade level to assist with shielding prompt neutron radiation. Using standard ISOL (Isotope Separator On-Line) target/ion source techniques the radionuclides are extracted and ionized, mass separated, and then sent either directly to an experimental area for research with ion or atom traps, or on to the secondary-beam accelerator. All secondary beamlines will be at the elevation of those in the existing ATLAS facility. Acceleration of these very low $\mathrm{q} / \mathrm{m}$ ions requires a sequence of three new subsystems: a short, low-frequency RFQ and two new sections of superconducting linac optimized for these low charge-state ions. After initial acceleration to the $0.5-1.0 \mathrm{MeV}$ per nucleon energy range the secondary beams can be delivered to a new experimental area for astrophysics experiments (labeled "Astrophysics", in Fig. 1). This area is in the existing ATLAS building, in the room presently occupied by the tandem injector for ATLAS. For further acceleration to the 1 to $15 \mathrm{MeV}$ per nucleon range, the beam merges into the present ATLAS beamline at the south end of this room. The capability of ATLAS to accelerate stable beams will remain independent of the added radioactive beam capability, both during construction and afterwards.

Table II. Driver Linac Specifications

Injector RFQ/Linac:

$5 \mathrm{MeV} / \mathrm{u}$ output @ $\mathrm{q} / \mathrm{m}=1 / 6$, (30 MV)

Main Linac:

$100 \mathrm{MeV} / \mathrm{u}$ output $@ \mathrm{q} / \mathrm{m}=$ $8 / 18,(215 \mathrm{MV})$

Duty Cycle:

Input Power:

$2 \% @ 120 \mathrm{~Hz}$

$1 \mathrm{MW}$

Output Energy Variability:

Controls:

\section{PRODUCTION METHODS}

The basic concept is to use a conventional drift-tube linac with $100 \mathrm{~kW}$ beam power available for a variety of light ions as indicated in Table I. The essential specifications of the driver linac are given in Table II.

Secondary beam intensities have been calculated using a variety of production mechanisms, proven target/ion source methods where known [3], and the efficiencies of bunching, stripping, etc. in the post acceleration. A table of specific beam intensity predictions for this facility is given in the working paper discussed above. A common problem for many second-generation radioactive beam facilities is learning to deal with very high power densities in the production targets. A large collaboration is currently preparing to test a new geometry target system with a $100 \mathrm{~kW}, 800 \mathrm{MeV}$ proton beam at the ISIS accelerator at the Rutherford Laboratory[4]. Continued R\&D on high power targets and associated ion sources is important for advanced radioactive beam facilities worldwide.

One production mechanism which has been investigated for this facility is indicated schematically in Fig. 2. This method separates the issue of the primary target which must dissipate the $100 \mathrm{~kW}$ beam power from that of the isotope production target/ion source combination. Quantitative yields from such a geometry were measured recently by an ANL/MSU collaboration using a low intensity, $200 \mathrm{MeV}$ deuteron beam at the NSCL. Yields of a variety of shortlived fission products, including ${ }^{132} \mathrm{Sn}$, were determined. Scaling the measured yields to $0.5 \mathrm{~mA}$ deuteron beam and a $100 \mathrm{~g} / \mathrm{cm}^{2}$ secondary uranium target gives $10^{13}{ }^{132} \mathrm{Sn} / \mathrm{sec}$ produced in the ion source/target system.

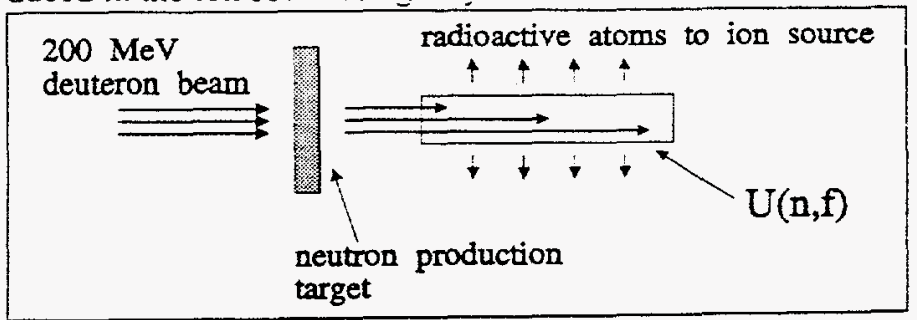

Figure 2. A conceptual layout showing the basic idea of using a $200 \mathrm{MeV}$ deuteron beam to generate an intense secondary beam of neutrons for the production of fission fragments. This separates the problems ofthe high power in the primary beam from the secondary target/ion source system. 


\begin{tabular}{|c|c|c|c|c|c|c|c|c|c|c|}
\hline \multicolumn{11}{|c|}{ Worksheet for the Secondary Beam Accelerator for the Argonne Exotic Beam Laboratory } \\
\hline & & & & & & & & & $\therefore$ & \\
\hline \multicolumn{4}{|c|}{ Driver Accelerator: } & \multicolumn{6}{|c|}{$200 \mathrm{MV}$ Linac, $\mathrm{q} / \mathrm{m}=0.5,100 \mathrm{~kW}$ beam power, $120 \mathrm{~Hz}$} & \\
\hline & & & & & & & & & & \\
\hline \multicolumn{4}{|c|}{ Radioactive Beam Accelerator: } & & \multicolumn{2}{|c|}{${ }^{132} \mathrm{Sn}$ Example } & \multirow[t]{2}{*}{$A=$} & \multirow[t]{2}{*}{132} & & \\
\hline & & & & & & & & & & \\
\hline Voltage & & & & Accel. & & & & & & \\
\hline gain & $\mathrm{q}$ & $\mathrm{T} / \mathrm{A}$ & velocity & length & efficiency & efficiency & intensity & intensity & Device: & Comments: \\
\hline \multirow[t]{2}{*}{ (MV) } & & $\mathrm{MeV} / \mathrm{A})$ & $(\mathrm{v} / \mathrm{c})$ & (m) & (this step) & (cumulat.) & (ions/sec) & (part. na) & & \\
\hline & & & & & & & $1.0 \mathrm{E}+13$ & & primary production rate & $100 \mathrm{~g} / \mathrm{cm}^{2}$ UC target \\
\hline \multirow[t]{2}{*}{0.1} & 1 & 0.0008 & 0.0013 & & 0.03 & 0.030 & $3.0 \mathrm{E}+11$ & 50.0 & ion source \& release & $4 \pi \mathrm{mm}-\mathrm{mr}$ \\
\hline & & & & & 0.80 & 0.024 & $2.4 \mathrm{E}+11$ & 40.0 & isobar separation & resolution $-30,000$. \\
\hline & 1 & 0.003 & 0.003 & 1.0 & 1.00 & 0.024 & $2.4 \mathrm{E}+11$ & 40.0 & onto HV platform & \\
\hline & & & & & 0.65 & 0.016 & $1.6 \mathrm{E}+11$ & 26.0 & prebunch/rebunch & \\
\hline 1.0 & 1 & 0.011 & 0.005 & 2.0 & 0.95 & 0.015 & $1.5 \mathrm{E}+11$ & 24.7 & RFQ on HV platform & $12 \mathrm{MHz}$ RFQ \\
\hline$-0.3 !$ & 1 & 0.008 & 0.004 & 1.0 & 1.00 & 0.015 & $1.5 \mathrm{E}+11$ & 24.7 & leave HV platform & \\
\hline 0.0 & 2 & 0.008 & 0.004 & & 0.40 & 0.006 & $5.9 \mathrm{E}+10$ & 9.9 & strip and rebunch & Gas stripper \\
\hline 2.0 & 2 & 0.039 & 0.009 & 2.0 & 0.95 & 0.006 & $5.6 \mathrm{E}+10$ & 9.4 & $24 \mathrm{MHz}$ linac & $S C$ folded resonator \\
\hline 30.0 & 2 & 0.493 & 0.033 & 15.0 & 0.95 & 0.005 & $5.4 \mathrm{E}+10$ & 8.9 & $48 \mathrm{MHz}$ linac & PII-type, 4 gap \\
\hline & $20^{\circ}$ & 0.493 & 0.033 & 1.0 & 0.20 & 0.0011 & $1.1 \mathrm{E}+10$ & 1.8 & strip to $\mathrm{q} / \mathrm{m}=0.15$ & Foil stripper \\
\hline & $20^{\circ}$ & 0.493 & 0.033 & 2.0 & 1.00 & 0.0011 & $1.1 E+10$ & 1.8 & rebunch & \\
\hline 4.0 & 20 & 1.099 & 0.049 & 3.0 & 0.95 & 0.0010 & $1.0 \mathrm{E}+10$ & 1.7 & $72 \mathrm{MHz}$ matching linac & PI-type, 4-gap \\
\hline 40.0 & 20 & 7.160 & 0.123 & 25.0 & 0.90 & 0.0009 & $9.1 E+09$ & 1.5 & out of ATLAS & existing accelerator \\
\hline
\end{tabular}

The spreadsheet shown above starts with these measured/scaled yields for ${ }^{132} \mathrm{Sn}$ in the production target and then lists the various ionization, bunching, acceleration, and stripping stages of the ISOL and secondary beam complex to illustrate, for a specific example, the predicted beam intensity for this facility.

\section{POST ACCELERATOR}

An essential feature of the post accelerator is to preserve the excellent beam quality currently available at ATLAS for stable beams of any mass up to uranium in the energy range from $6-15 \mathrm{MeV}$ per nucleon.

This work is supported by the U.S. Department of Energy Nuclear Physics Division.

\section{REFERENCES}

[1] The IsoSpin Laboratory, Research Opportunities with Radioactive Beams, LALP report 91-51 (1991).

[2] European Radioactive Beam Facilities Report of NuPECC Study Group (1993).

[3] H. L. Ravn et al., Nucl. Instr. and Meth. B88, 441 (1994).

[4] J. R. J. Bennett et al., "A Test Facility for Radioactive Ions Generated by Intense Beams of High Energy Protons" Proceedings of the Workshop on the Production and Use of Intense Radioactive Beams at the IsoSpin Laboratory, Oak Ridge, TN (1992).

\section{DISCLAIMER}

This report was prepared as an account of work sponsored by an agency of the United States United States Government nor any agency thereof, nor any of their Government. Neither the United States Gor implied, or assumes any legal liability or responsiemployees, makes any warranty, express or inplied, or any information, apparatus, product, or bility for the accuracy, completeness, or usefulness of any inforinge privately owned rights. Referprocess disclosed, or represents that its use would nocess, or service by trade name, trademark, ence herein to any specific commercial product, process, or se imply its endorsement, recommanufacturer, or otherwise does not necessarily constitute or imply its ency thereof. The views mendation, or favoring by the United States Government or any ate or reflect those of the and opinions of authors expressed herein do not 